\title{
The relationship between internet addiction and personality traits in Slovak secondary schools students
}

\author{
M. HOSŤOVECKÝ AND P. PROKOP
}

\begin{abstract}
A new phenomenon, which increasingly rises among the young generation all over the world, is Internet addiction. Information and communication technology (ICT) has a major influence not only on individual sectors of the national economy (services, industry, agriculture, etc.), but also on free time activities and interests of the young generation. ICT-related free time activities of the young generation have notably changed over the last decade (Slovakia was connected to the Internet in November 1992). The aim of the research was to determine the symptoms of Internet addiction in Slovak secondary school students, i.e. to detect significant differences between the following: a personality trait - addiction, addiction - age, addiction - a place of residence, etc. The standardized questionnaire was used in all regions of Slovakia. We collected data by means of an online questionnaire over the period of more than six months. The research results show that female have more potential to become addicted than male, which could be caused by feelings and sadness (Ha \& Hwang., 2014). Some other significant results show that more extroverted students are less Internet-addicted than their less extroverted counterparts. According to Zamani, extroverts prefer social and face-to-face interaction with others (Zamani et al., 2011). Other questions focused on neuroticism - emotional stability, where more neurotic students were more addicted than less neurotic students. Finally, significant results were related to residence. Findings showed that students who come from cities (towns) had higher symptoms of Internet addiction than villagers. Other details of this research are shown in the results and discussion section.
\end{abstract}

Mathematics Subject Classification 2000: 97C30 [Psychology of and research in mathematics education]

General Terms: addiction, personality, students, internet.

Additional Key Words and Phrases: Big Five test, Internet addiction, online questionnare.

\section{INTRODUCTION}

Nowadays, computers and other information technologies play a crucial role in the learning and teaching process. Computers are also an integral part of student's everyday life outside of school and they are used for writing homework or essays, as a part of every school subject, not only at informatics classes; this pattern has been recently documented at almost every Slovak school (Demkanin, 2008). The Internet has long been not only a medium allowing sharing information in text or graphic form or a medium providing "chat" and e-mail based on a text. Today, in connection 
with the Internet constantly increasing development of technical means (e.g. parameters and data), networks offer a wider range of options for developing interactive communication (Host'ovecký \& Zat'ková, 2010; Horrigan \& Rainie, 2006). The strong integration between social networking and the Internet represents a new Copernican revolution for net users. Most of them choose to use social media platforms for regulating their personal and interpersonal relationships, communications and sociability with peers (Hawi, 2012; Kalkan, 2012; Odaci \& Çelik, 2013).

Today's youth spend a lot of time on the Internet, whether it's gaming, watching movies or social networking. As for these activities, there are a number of disadvantages related to using the Internet by high school students. The explosive growth of the Internet in the last decade has had a huge impact on communication and interpersonal behaviour. The Internet was originally designed to facilitate communication and research activities. However, the dramatic increase in the use of the Internet in recent years has led to pathological use - Internet addiction (Takeshi, 2006). Many students even feel out of control and helpless and report serious impairments in their lives as a result of their Internet use (Orzack, 1999; Young, 1996). Internet addiction (also referred to as Internet dependence) occurs when excessive Internet use begins to impact other areas of a person's life. For example, many people have reported experiencing marital problems because of compulsive Internet use (Bocij, 2006). Addictive use of the Internet is a new phenomenon.

Addiction is defined as a primary, chronic disease affecting brain centres, motivation, memory and related circuits. Dysfunction of these circuits leads to characteristic biological, psychological, social and spiritual manifestations. Addiction is characterized by damage to behavioral control and desire, a failure to recognize significant issues and interpersonal relationships, and dysfunctional emotional reactions. Like other chronic diseases, addiction often involves relapse cycles. Without treatment, addiction is progressive and may result in disability or premature death (American Society of Addiction Medicine, 2011). According to the definition in the Mosby's Medical Dictionary, it is a compulsive, uncontrollable addiction to chemical substances, a habit or a practice to such an extent that stopping 
the activity may cause severe emotional, mental or physiological reactions. The use of the term uncontrollable excludes cases in which an individual successfully tries to control their behaviour (West, 2013). We were examining differences in addiction between sexes, age groups, places of residence (city - the country), regions (Western, Middle, Eastern Slovakia), classes (lower grades 1,2 and upper grades $3,4)$, extroverts and introverts, more and less agreeable students, more and less conscientious students, more nervous and calmer students.

Before 1997, the number of computer users was very small and this technology was used only by military or large financial centres. Nowadays, however, the number of computer and Internet users increases on a daily basis (Young, 1996). Slovakia was connected to the Internet in November 1992. After 2000, the situation changed. More and more universities and secondary schools were connected to the Internet and the quality of connection improved year after year. Nowadays, after almost 25 years, more than $81 \%$ households have an access to the Internet in Slovakia (over 4.4 million inhabitants, Eurostat 2016). Computers have thus also become a sort of a companion of today's youth. The young generation uses computer in their everyday life. One of the areas affected by the influence of computers is free time. Much research (e.g., Vrabec, 2009; Hirzalla \& Zoonen, 2008; Uyenco \& Kingdon, 2010) has confirmed that children at a younger and older school age, such as adolescents, spend an average of $1.5-3$ hours on the computer.

The past decade has seen a tremendous increase in internet use and computermediated communication (Fox et al., 2001). Especially the young generation carries out a lot of work with the help of a computer. The society expects pupils already in the first grade of primary school to have at least partially developed skills in using some of the "new" media, e.g. computer, smart phone, tablet. Computer and the Internet have become an indispensable passion for them. The young generation uses computers and the Internet more successfully and faster than previous generations (Tosun \& Baris, 2011; Mišút \& Pribilová, 2013). It creates new ways for citizens to communicate, congregate and share information of a social nature (Kedem, 1999). The Internet provides an array of tools for people to use for information retrieval and communication in individual, group and mass contexts, but can current notions of 
media be used to define communication on the Internet? They can no longer imagine their lives without a computer and internet connection. Computers help students in their studies and in communication with their classmates, teachers, friends and family, but have also become one of the main free time activities. Nowadays, television, radio, but also books and magazines, sport, personal contact and conversations are to a large extent substituted by computers. The well-known phrase "Everything's on the Web" is slowly becoming reality.

Another very important factor of using the Internet is user's personality. Personality has a psychological impact on how subjects interact with information technologies. According to Amichai-Hamburger, these studies are decisive because personality traits are relevant factors in determining subjects' behaviour when using Internet technologies (Amichai -Hamburger, 2002).

Personality not only defines the subjects' behavioural style but also represents relatively enduring characteristics of subjects, and it refers to all aspects of individuality. Human activities and types of behaviour are consistent with specific traits of personality.

There are three ingredients required for the initiation of scientific research on traits: systematic data collection, statistical techniques for data analysis, and development of testable theories. These prerequisites became available around the beginning of the $20^{\text {th }}$ century. Of key importance were the new techniques of correlation and, somewhat later, factor analysis (Matthews et al., 2009; Gorsuch, 1983).

One way to study the relationship between subjects' personality traits and the use of the Internet is to apply specific conceptual frameworks, such as the Big Five factor model (Montag, Jurkiewicz, \& Reutera, 2010). Following the advances in research, previous investigations established a strong connection between personality traits and Internet addiction (Chang \& Law, 2008; Correa, Hinsley, \& de Zúñiga, 2010; Landers \& Lounsbury, 2006; Rice \& Markey, 2009). Moreover, personality traits, parenting and familial influence, alcohol use, and social anxiety are considered to be predictive factors of Internet addiction disorder (Ko et al., 2012). The exponential use of the Internet has stimulated debate on examining how 
personality traits impact on the use of technologies, particularly the Internet, social networking, virtual environments, online and offline games, and so on. Thus, rather than investigate only the relationships between Internet overuse and subjects' behaviour, current research work is interested in exploring the influence of personality traits on Internet addiction risks (Buckner et al., 2012; Landers \& Lounsbury, 2006; Ryan \& Xenos, 2011).

When the effect of gender was taken into consideration, males had significantly higher PIU scores than females (Ozcan \& Buzlu, 2007; Tsai et al., 2009; Young, 1996). Internet use also has an impact on the life of school-age young people. Young and Rogers state that difficulties concerning studying, for instance a drop in grades and changing sleep patterns can occur when school-age youngsters spend too much time on the web (Young \& Roger, 1998).

Further research using various samples, such as elderly, adults, and adolescents, is necessary to evaluate the divergent validity of the findings. In addition, the effects of some other variables on PIU should be taken into consideration in future studies, such as personality variables neuroticism (Tsai et al., 2009), self-esteem (Yang \& Tung, 2007; Douglas et al., 2008; Ko et al., 2007), and conscientiousness (Durak \& Senol-Durak, 2010), life satisfaction (Stepanikova, Nie, \& He, 2010) and subjective well-being (Kraut et al., 1998). The results show that the five dimensions of personality add significantly to the variance explained by gender and Facebook experience concerning time spent on Facebook (De Cock et al., 2014).

Besides developed countries, one of the countries where addiction is starting to show is China. According to Ferraro et al.: "Internet addiction is a problem not only for adolescents in China; it also presents headaches for parents and teachers all over the world“ (Ferraro et al., 2007). Other research realized in Greece, Siomos and his colleagues (Siomos et al., 2008) surveyed 2,200 Greek adolescent students and showed that $8.2 \%$ of them were addicted to the Internet, mainly male students who play online games and visit Internet cafés. In Iran, a study conducted in Iranian high schools revealed that, among 1,968 high school students, 977 students were Internet users: 37 were classified as Internet addicts, 304 as possible Internet addicts, and 636 as moderate users. Researchers found that Internet addicts were lonelier than 
moderate users and had lower self-esteem and poorer social skills (Ghassemzadeh et al., 2008). Because accessibility to computers in Slovakia was, at least according to past report, much lower compared with western countries (Fančovičová \& Prokop, 2008) and no reports concerning IAD in Slovakia exist, we investigated the prevalence of IAD among Slovak high school students.

Griffiths proposed the concept of „technological addiction“, which is nonchemical but behavioral bin nature and involves excessive human-machine interaction. Technological addiction can be either passive, such as viewing television, or active, such as gaming on the computer or chatting online usually comprises inducing and reinforcing features that may contribute to the promotion of addictive tendencies (Griffiths 1996). Internet addiction disorder (IAD) was first proposed by Ivan Goldberg in 1995. Derived from the substance-dependence criteria of the Diagnostic and Statistical Manual of Mental Disorders (4th Ed. DSM-IV American Psychiatric Association, 1994), IAD is the first listed Internet-related disorded. It is defined as a behavioral addiction consisting of six core components: salience, mood modification, tolerance, withdrawal symptoms, conflict, and relapse (Griffiths, 1998). Internet Addiction Disorder (IAD) ruins lives by causing neurological complications, psychological disturbances, and social problems.

\section{METHODS}

\section{- Purpose of study}

The aim of our research was to determine Internet addiction in students of secondary professional schools and, at the same time, to find out how student's character and personality affects the time spent on the computer in relation to the risk of development of addiction.

These hypotheses were evaluated:

- Males will show a higher rate of Internet addiction than females.

- Students from lower grades will be more addicted than students from upper grades. 
- Students from cities will show a statistically significant higher rate of Internet addiction than students coming from the village.

- Extroverted students will be less addicted to Internet than introverted students.

- More agreeable students will be less addicted to Internet than less agreeable students.

- More conscientious students will show a lower rate of Internet addiction than less conscientious ones.

- More neurotic students will be more addicted than less neurotic students.

- Students who are more open in their behaviour will be less addicted to Internet than students who are more closed.

\section{- $\quad$ Research instrument}

An anonymous questionnaire was used in the research that we carried out to determine Internet addiction in secondary school students. It was divided into three sections.

In the first section of the questionnaire, a short introductory text about the intent of the questionnaire was presented followed by demographic data about a student: age, sex, place of residence (the village/city), region, secondary school's specialisation, student's current grade.

In the second section, the Internet Addiction Test (hereinafter referred to as IAT) by Kimberly Young (Year) was used. It is the first ratified and reliable method of measurement of addictive Internet use. This questionnaire was translated from English into Slovak and contained 18 items investigating questions regarding Internet addiction. Questions were translated freely; however, the emphasis was on maintaining the meaning and structure of the questionnaire. Each item in the questionnaire was evaluated by a 5-point Likert scale using the following description: "strongly agree" (5 points), "slightly agree" (4 points), "neutral" (3 points), "slightly disagree" (2 points), "strongly disagree" (1 point). For determining Internet addiction, we used a differentiation scale of addicted and non-addicted users by K. Young. 
In the third section, a questionnaire for assessing personality traits of students (10-item short version of the Big Five Inventory) was used in comparison with their access to the Internet by Rammstedt \& John. The Big Five Inventory is one of the most widespread personality models. Thus, basic factors or personality traits according to the Big Five Model are neuroticism, openness to experience, extraversion, agreeableness and conscientiousness. As a part of BFI, a 5-item scale of responses from "strongly disagree" (1) to "strongly agree" (5) was designed. Individual's personality may be found at a various level of the scale. The Big Five Model is commonly used in various cultural areas as well as some areas of psychological research (Rammstedt \& John, 2007).

The present study was conducted online, which affords a high degree of anonymity, which elicits more candid responses to questions about socially undesirable behaviour and emotions than do paper and pencil methods or interview methods (Locke and Gilbert, 1995; Musch et al., 2001). In addition, internet surveys are a convenient, user-friendly, comfortable, and secure data gathering method (e.g., Campos et al., 2011; Lewis, et al., 2009; van Gelder et al., 2010).

\section{- Participants}

Participants were 707 high school students (340 males and 367 females) with the mean age of 16.9 years ( $\mathrm{SE}=0.06$, range: $15-21$ years). The research sample consisted of secondary school students from all regions of Slovakia, i.e. the Banská Bystrica, Bratislava, Košice, Nitra, Prešov, Trenčín, Trnava and Žilina region. Students participated in the research on a voluntary basis. Respondents were addressed by the school's management which received an accompanying letter clarifying the research and its purpose as well as the internet link to an electronic questionnaire. The alternative way of addressing them was a social network Facebook. We contacted all secondary professional schools in all regions of Slovakia, i.e. 448 secondary schools, by means of sending an e-mail and via Facebook. Response rate was $5.5 \%$ which represents 25 secondary schools in Slovakia. 
Secondary professional schools were divided by their specialisation following the International Standard Classification of Education (hereinafter referred to as ISCED) by UNESCO. The reason was the fact that this instrument serves as a means of comparing, compiling and presenting statistical data on education. According to this categorization, secondary professional schools belong to category ISCED 3 Upper secondary education (secondary schools with a school-leaving exam). Representation of the number of respondents according to ISCED 3 specialisation who participated in our research is shown below:

- $\quad$ Social sciences and humanities (music, dramatic arts, history...) $10 \%$ (71 students);

- Social sciences, business, law (economics, journalism, tourism...) $15 \%$ (108 students);

- Natural sciences, mathematics, computer sciences (geodesy, biology, chemistry...) $7 \%$ (47 students);

- Engineering, production, construction (mechanics, electronics, architecture...) $32 \%$ (228 students);

- Agriculture and veterinary medicine (food, horticulture...) 2\% (15 students);

- Health and health care (social work, pharmaceutics...) 12\% (84 students);

- Services (hotel, security, hairdressing and beauty treatment services...) $22 \%$ (154 students).

About half of participants (56\%) reported to live in villages and remaining $46 \%$ reported to live in cities. Pursuant to the Act of the National Council of the Slovak Republic No. 369/1990 on Municipal Establishment, Slovakia is divided into 8 large regions and 79 smaller counties. Each of these 8 so-called Higher-Tier or UpperTier Territorial Units (VÚC - Vyššie Územné Celky) are named after the largest city in that region. Each of the counties has some cities and villages. There is not a classification in Slovakia which determines the difference between a city and a town. We can define a city and a village as follows. 
A Village is a clustered human settlement which is smaller than a city. Today, there are 2,933 villages in all regions of Slovakia. About $45 \%$ of Slovaks live in villages with less than 5,000 inhabitants, and 14\% in villages with less than 1,000.

A city is a human settlement larger than a village. Nowadays, there are 140 cities in Slovakia (2017). These requirements are determined by the Act of the National Council of the Slovak Republic called "the Act on Municipal Establishment". A city can be considered every community or a place of living which meets the requirements listed below:

- an economic, administrative and cultural center or a tourist center, or a spa,

- provides services for inhabitants of surrounding villages,

- has a secured transport connection with surrounding villages,

- has an urban building character at least in some parts of its area,

- $\quad$ has at least 5,000 inhabitants (§ 22, Act No. 369/1990).

\section{- Statistical analyses}

Multiple regression was applied to investigate associations between Big Five personality traits (agreeableness, extraversion, conscientiousness, neuroticism and openness), residence (village/city), the region of student's origin - the part of Slovakia (western, central or eastern region), secondary school focus and grade (independent variables) and internet dependence (dependent variable). Continuous predictors were initially checked for normality with Kolmogorov-Smirnov test. Only mean scores of the Internet Dependence scale differed from normal distribution, thus Box-Cox $(x+1)$ transformation was applied in order to achieve normality. All VIF (variance inflation factor) values were $<2$ suggesting that there was no collinearity between variables in our sample (Allison, 1999). 


\section{RESULTS}

Multiple regression resulted in significant model $(\mathrm{R} 2=0.12, \mathrm{~F}(10,696)=9.28$, $\mathrm{p}<0.001)$ that explained $12 \%$ of total variance of the results. Detailed report is shown in Table 1. Participants who scored high in Extraversion and Conscientiousness domains showed lower Internet Dependence score. In contrast, Neuroticism showed positive associations with Internet Dependence score. Agreeableness and Openness were not associated with the Internet Dependence score. Perhaps surprisingly, females showed higher Internet Dependence score than males and participants from cities scored higher than participants from villages. Other correlations were not statistically significant (Table 1).

Table 1. Multiple regression on Internet Dependence score. Significant associations are marked bold.

\begin{tabular}{lllllll}
\hline & $\beta$ & $\mathrm{SE}$ of $\beta$ & $\mathrm{B}$ & $\mathrm{Se}$ of B & $\mathrm{t}(696)$ & $\mathrm{P}$ \\
\hline Intercept & & & 5.556 & 1.245 & 4.462 & $<\mathbf{0 . 0 0 1}$ \\
\hline Extraversion & -0.117 & 0.037 & -0.007 & 0.002 & -3.143 & $\mathbf{0 . 0 0 1}$ \\
\hline Agreeableness & -0.050 & 0.036 & -0.003 & 0.002 & -1.398 & 0.163 \\
\hline Conscientiousness & -0.152 & 0.038 & -0.010 & 0.002 & -4.030 & $<\mathbf{0 . 0 0 1}$ \\
\hline Neuroticism & 0.132 & 0.037 & 0.008 & 0.002 & 3.554 & $<\mathbf{0 . 0 0 1}$ \\
\hline Openness & 0.004 & 0.036 & 0.000 & 0.003 & 0.113 & 0.910 \\
\hline Gender & -0.119 & 0.037 & -0.026 & 0.008 & -3.187 & $\mathbf{0 . 0 0 1}$ \\
\hline Residence & -0.091 & 0.036 & -0.020 & 0.008 & -2.499 & $\mathbf{0 . 0 1}$ \\
\hline Region & 0.052 & 0.036 & 0.003 & 0.002 & 1.434 & 0.152 \\
\hline Type of secondary school & -0.053 & 0.036 & -0.004 & 0.003 & -1.446 & 0.149 \\
\hline Grade & -0.049 & 0.036 & -0.005 & 0.004 & -1.335 & 0.182 \\
\hline
\end{tabular}




\section{DISCUSSION}

The present study offers findings that the age of Internet-addicted Slovak adolescents ranges from 15 to 21 . This is the first study which compares the Internet addiction and Big Five personality factors of secondary school students in Slovakia. It gives us understanding of behavioural addiction and its personality correlates. Therefore, the findings support some of our above mentioned hypotheses. A representative web-based online survey was used to examine the relationship between personal traits and Internet addiction among 707 Slovak adolescents. Our findings are in accordance with previous researches carried out in some other regions of Europe, Asia and the United States.

The exponential use of the Internet has stimulated debate on examining how personality traits impact the use of technologies, particularly the Internet, social networking, virtual environments, online and offline games, and so on. Thus, rather than investigate only the relationships between Internet overuse and subjects' behaviour, current research work is interested in exploring the influence of personality traits on Internet addiction risks (Buckner et al., 2012; Landers \& Lounsbury, 2006; Ryan \& Xenos, 2011). Internet use also has an impact on the life of school-age young people. Young and Rogers state that difficulties concerning studying, for instance a drop in grades and changing sleep patterns can occur when school-age youngsters spend too much time on the web (Young and Rogers, 1998).

\section{Gender}

The present study investigated whether males are more Internet addicted than females. It was surprising to find that females obtained higher score than males in web self-assessment questionnaire focused on Internet addiction. In line with Tsai et al. (Tsai \& Lin, 2004), we confirm that findings may contradict the gender stereotype in the use of technology. We can see similar results in the increase of female scores compared to males in some technological areas, e.g. mobile phone addiction. There are some findings that mobile phone addiction was associated with female gender. This finding is in line with previous studies (Andreassen et al., 2013; Augner \& Hacker, 2012). 
This result could be caused by feelings such as sadness, which is in line with $\underline{\mathrm{Ha}}$ (Ha \& Hwang, 2014) who states that when males and females are stressed, females are encouraged to express feelings such as sadness and to use more emotional strategies, whereas males are discouraged from expressing their feelings, and they tend to adopt distracting or aggressive strategies. Gender differences in preferred online activities may contribute to a higher risk of Internet addiction in females who are depressed (Ha \& Hwang, 2014).

\section{Extroversion \& Neuroticism}

Results showed that more extroverted participants are less Internet-addicted than less extroverted participants. It appears that students with high extraversion scores prefer social and face-to-face interaction with others to interaction with the virtual world. On the contrary, more introverted students avoid contact with other people because of their shyness, so they communicate with the virtual world more (Zamani et al., 2011). Introverted (or less extraverted) individuals fail to cope with emotional and physical stress effectively, have difficulty in establishing social relationships and, thus, are relatively more susceptible to addiction. Some previous researches, including the study of Batıgün (Batıgün \& Kilic, 2011) and Floros (Floros \& Siomos, 2014), indicate that people with low levels of extraversion use the Internet more frequently and may be at a higher risk of internet addiction. Our findings confirm some previous studies which investigate extroversion (Andreassen et al., 2013; Chou et al., 2005).

Neuroticism or emotional stability is one of the five components of Big Five personality model. In our study, we predicted that more neurotic students will be more addicted than less neurotic students. Our findings have confirmed our hypothesis: Slovak secondary school students who are more neurotic are more Internet-addictive than their less neurotic counterparts. Our findings are in line with and confirm some other research in this field from different regions from all over the world. Kunimura and Thomas assessed 113 students at Loyola Marymount University and found a significant positive relation between neurosis and Internet dependency as well as a significant negative relation between extroversion and 
Internet dependency (Kunimura \& Thomas, 2000; Zamani et al., 2011). Results of another study confirm that neuroticism was positively associated with internet addiction (Saini et al., 2016)

\section{Residence}

The main findings showed that students coming from cities (towns) had higher symptoms of Internet addiction than villagers. It could be caused by the fact that villagers spend more time in the garden (gardening, field work, work in orchards, etc.), in nature (walking, tourism) or sporting (cycling, natural swimming, mountaineering, etc.). It is, in particular, very typical of some parts of our country (the northern, southern and eastern part of Slovakia) that young people are helpful to parents. Our findings are in accordance with previous studies (Lićwinko, KrajewskaKułak \& Lukaszuk, 2011) showing similar results: students living in the city had more problems with Internet addiction than students from the villages.

\section{Limitations}

The present study has some limitations, which must be addressed. Our sample size was 707 participants (340 males and 367 females). We wanted to obtain a more representative sample size from schools in Slovakia. Also, even though the present study sample size provided acceptable statistical power (Cohen, 1988), it was still quite small. Thus, cross-validation of the current study with larger samples should be carried out. The instruments used in the present study were standardized. Other studies in this field should therefore use longitudinal designs in order to better assess the directionality between the concepts. In addition, future studies should use larger and more representative samples in terms of gender, age, etc. (Andreassen, Griffiths, Gjertsen, Krossbakken,,Kvam, Pallesen, 2013).

Further research using various samples, such as elderly, adults, and adolescents, is necessary to evaluate the divergent validity of the findings. In addition, the effects of some other variables on PIU should be taken into consideration in future studies, such as personality variables (neuroticism (Tsai et al., 2009), self-esteem (Yang \& Tung, 2007; Douglas et al., 2008; Ko et al., 2007), and conscientiousness (Durak \& 
Senol-Durak, 2010), life satisfaction (Stepanikova, Nie, \& He, 2010) and subjective well-being (Kraut et al., 1998).

In addition, the validity of some of the participants' answers may be questionable and motivational factors of participants responding to this study should be discussed as well. An online questionnaire without personal involvement and without experts in the topic of Internet addiction was used. Therefore, some answers might reflect different level of scores. Also, all data in the present study was based on self-report, so the results may have been influenced by the common method bias (Podsakoff et al., 2003).

\section{CONCLUSION}

Nowadays, Internet addiction disorder (AID) belongs to disorders that not only students, but anyone else can have. The aim of this research was to find out whether secondary school students from secondary schools in Slovakia show potential signs of Internet addiction. We were examining addiction between sexes, older and younger students, types of specialization of secondary professional schools, and personality characters (introvert-extrovert). Our results confirm that:

- female scored higher than male in the self-assessment questionnaire;

- more extroverted participants had higher symptoms of Internet addiction than less extroverted participants;

- more neurotic participants had higher symptoms of Internet addiction than less neurotic participants;

- less conscious students had higher symptoms of Internet addiction than more conscious students;

- respondents living in the cities were more Internet-addicted than respondents living in villages.

In another prospective future study, it could be interesting to see the relationship and the comparison between Internet addiction and personality traits of Slovak university students in different fields of study: science, medicine, engineering, agriculture, economy, law and the relationship between private and public university students. 


\section{ACKNOWLEDGMENTS}

Many thanks to students who participated in the research. Many thanks to $\mathrm{Mr}$. Halás for improve the English language.

\section{REFERENCES}

ALLISON, P. D. 1999. Multiple Regression: a primer. Pine Forge Press: Thousand Oaks. AMERICAN PSYCHIATRIC ASSOCIATION. 1994. DSM-IV. $4^{\text {th }}$ Ed.

AMERICAN SOCIETY OF ADDICTION MEDICINE. 2011. Definition of Addiction, http://www.asam.org for-the-public/definition-of-addiction

AMICHAI-HAMBURGER, Y. 2002. Internet and personality. Computers in Human Behavior, 18, 1-10.

ANDREASSEN, C.S., GRIFFITHS, M.D., GJERTSEN, S.R., KROSSBAKKEN, E., KVAM, S., PALLESEN, S. (2013). The relationships between behavioral addictions and the five-factor model of personality. Journal of Behavioral Addictions, 2(2), 90 - 99.

AUGNER, C., HACKER, G. W. 2012. Associations between problematic mobile phone use and psychological parameters in young adults. In: International Journal of Public Health, 57, 437 441.

BATIGÜN, A.D., KILIC, N. 2011. The relationships between internet addiction, social support, psychological symptoms and some socio-demographical variables. Türk Psikol Derg, 26 (67), 1 -10 .

BOCIJ, P. 2006. The dark side of the internet: protecting yourself and your family from online criminals. ISBN: 0-275-98757-X

CAMPOS, J. A., ZUCOLOTO, M. L., BONAFE, F. S., JORDANI, P. C., MAROCO, J. 2011. Reliability and validity of self-reported burnout in college students: A cross randomized comparison of paper-and-pencil vs. online administration. In: Computers in Human Behavior, 27, 1875-1883.

COHEN, J. 1988. Statistical power analysis for the behavioral sciences (2nd ed.). New Jersey: Lawrence Erlbaum.

CORREA, T., HINSLEY, A. W., DE ZÚÑIGA, H. G. 2010. Who interacts on the Web? The intersection of users' personality and social media use. In: Computers in Human Behavior, 26(2), 247-253. DOI: $10.1016 /$ j.chb.2009.09.003

CHANG, M.K., LAW, S.P.M. 2008. Factor Structure for Young's Internet Addiction Test: A confimatory study. Computers in Human Behavior. 24(6), 2597-2619.

ODACI, H., ÇELIK, Ç. B. 2013. Who are problematic internet users? An investigation of the correlations between problematic internet use and shyness, loneliness, narcissism, aggression and selfperception. Computers in Human Behavior 29(6), 2382-2387.

CHOU C., CONDRON L., BELLAND J.C.. 2005. A review of the research on Internet addiction. Educational Psychology Review, 17(4), 363-88.

De COCK, R., VANGEEL, J., KLEIN, A., MINOTTE, P., ROSAS, O., MEERKERK, G.J. 2014. Compulsive use of social networking sites in Belgium: prevalence, profile, and the role of attitude toward work and school. Cyberpsychology, Behavior and Social Networking, 17(3), 166-171. http://dx.doi.org/10.1089/cyber.2013.0029.

DEMKANIN, P. 2008. One small, but significant step in science education in Slovakia. In P. Demkanin, B. Kibble, J. Lavonen, J. G. Mas, \& J. Turlo Eds., Effective use of ICT in science education. 120-140. Edinburgh: University of Edinburgh, School of Education.

DOUGLAS A.C., MILLS J.E., NIANG M., STEPCHENKOVA S., BYUN S., RUFF;INI C., et al. 2008. Internet addiction: meta-synthesis of qualitative research for the decade 1996-2006. Computers in Human Behavior. 24(6), 302-744.

DURAK, M., SENOL-DURAK, E. 2010. Which personality traits are associated with cognitions related to problematic Internet use? Manuscript under evaluation.

FANČOVIČOVÁ, J., PROKOP, P. 2008. Students' attitudes toward computer use in Slovakia. Eurasia Journal of Mathematics, Science \& Technology Education, 4(3), 255 - 262.

FERRARO, G., CACI, B., D'AMICO, A., BLASI, M. D. 2007. Internet addiction disorder: An Italian study. In: CyberPsychology \& Behavior, 10(2), 170-175. 
FLOROS, G., SIOMOS, K. 2014. Excessive internet use and personality traits. In: Curr Behav Neurosci Reports, 1, 19-26.

FOX, S., RAINIE, L., LARSEN, E., HORRIGAN, J., LENHART, A., SPOONER, T., CARTER, C. 2001. Wired Seniors. The Pew Internet and American Life Project. Retrieved May 4th 2005 from: http://www.pewinternet.org/pdfs/PIP_Wired_Seniors_Report.pdf

GHASSEMZADEH, L., SHAHRARAY, M., MORADI, A. 2008. Prevalence of Internet addiction and comparison of Internet addicts and non-addicts in Iranian high schools. In: CyberPsychology \& Behavior, 11(6), 731-733.

GORSUCH, R. L., 1983. Factor Analysis, second edition, Hillsdale: Lawrence Erlbaum Associates.

GRIFFITHS, M. D. 1996. Gambling on the Internet: A brief note. In: Journal of Gambling Studies, 12, 471-473.

GRIFFITHS, M.D., HUNT, N. 1998. Dependence on computer games by adolescents. In: Psychology Reports, 82, 475-480.

HA, Y. M., HWANG, W. J. 2014. Gender Differences in Internet Addiction Associated with Psychological Health Indicators Among Adolescents Using a National Web-based Survey. In: International Journal of Mental Health and Addiction, 12 (5), 660. https://doi.org/10.1007/s 11469-014-9500-7

HAWI, N. S. 2012. Internet addiction among adolescents in Lebanon. In: Computers in Human Behavior 28(3): 1044-1053.

HIRZALLA, F., VAN ZOONEN, L. 2008. Usesofthe Web for Civic Participation: výskumná správa. London: Institute of Education. 140 pages. http://www.civicweb.eu/images/stories /reports/wp9civicwebdeliverable8.pdf

HORRIGAN, J., RAINIE, L. 2006. The internet's growing in life's major moments. Retrieved August 30, http://www/pewinternet.org/PPF/r/181/repo rtdisplay.asp

HOSŤOVECKÝ, M. ZAŤKOVÁ, T. 2010. Options for implementing videoconferencing system in a combined form of education. In: Acta Universitatis Facultatis Paedagogicae Tyrnaviensis. Ser. C - Trnava, 157-164.

KALKAN, M. 2012. Predictiveness of interpersonal cognitive distortions on university students' problematic internet use. In: Children and Youth Services Review 3(7), 1305-1308.

KEDEM, C. 1999. The social impact of the internet on our society. Retrieved August 30, 2006, http://www.math.umd.edu/ bnk/CAR/ project.htm.

KO, CH., YEN, J.Y., YEN, C.F., LIN, H.C., YANG, M.J. 2007. Factors predictive for incidence and remission of Internet addiction in young adolescents: A prospective study. In: CyberPsychology \& Behavior. 10, 545-551.

KO, CH., YEN, J.Y., YEN, C.F., CHEN, C.S., CHEN, C.C. 2012. The association between Internet addiction and psychiatric disorder: a review of the literature. In: Eur Psychiatry. 27(1), 1-8. https://doi.org/10.1016/j.eurpsy.2010.04.011

KRAUT, R., PATTERSON, M., LUNDMARK, V., KIESLER, S., MUKOPHADHYAY, T., SCHERLIS, W. 1998. Internet paradox: A social technology that reduces social involvement and psychological well-being? In: American Psychologist, 53(9), 1017-1031.

KUNIMURA, M., THOMAS, V. 2000. Summary and review of the NEO-PI-R personality test. Journal of LoyolaMary mount University. 2000;38(4):1-13

LANDERS, R. N., LOUNSBURY, J. W. 2006. An investigation of Big Five and narrow personality traits in relation to Internet usage. In: Computers in Human Behavior, 22, 283-293. doi:10.1016/j.chb.2004.06.001.

LEWIS, I., WATSON, B., WHITE, K. M. 2009. Internet versus paper-and-pencil survey methods in psychological experiments: Equivalence testing of participant responses to health-related messages. In: Australian Journal of Psychology, 61, 107-116.

LIĆWINKO, J., KRAJEWSKA-KUŁAK, E., \& ŁUKASZUK, C. 2011. Internet addiction among academic youth in Białystok. Progress in Health Sciences, 1(1), 124-130.

LOCKE, S. D., GILBERT, B. O. 1995. Method of psychological assessment, self-disclosure, and experiential differences: A study of computer, questionnaire, and interview assessment formats. In: Journal of Social Behavior and Personality, 10, 255-263.

MATTHEWS, G., DEARY, I. J., WHITEMAN, M. C. 2009. Personality traits (3rd ed.) Cambridge: Cambridge University Press. In Internet addiction in adolescents: Prevalence and risk factors. In: Computer in Human Behavior.

MIŠÚT, M., PRIBILOVÁ, K. 2013: Communication impact on project oriented teaching in technology supported education. In Lecture Notes in Electrical Engineering, 152 LNEE, 559-567. 
MONTAG, C., JURKIEWICZ, M., REUTER, M. 2010. Low self-directedness is a better predictor for problematic internet use than high neuroticism. In: Computers in Human Behavior, 26(6), 15311535. doi:10.1016/j.chb.2010.05.021

MUSCH, J., BRODER, A., KLAUER, K. C. 2001. Improving survey research on the world-wide web using the randomized response technique. In U-D. Reips and M. Bosnjak (Ed.), Dimensions of internet science (179-192). Lengerich: Pabst Science Publishers.

OZCAN, N.K. BUZLU, S. 2007. Internet use and its relation with the psychosocial situation for a sample of university students. In: Cyberpsychology and Behavior, 10(6), 767-772.

ORZACK, M. 1999. Computer addiction: Is it real or virtual? Harvard Mental Health Letter, 15(7), 8.

PODSAKOFF, P. M., MACKENZIE, S., Lee, J.Y., Podsakoff, P. N. 2003. Common Method Biases in Behavioral Research: A Critical Review of the Literature and Recommended Remedies. In: The Journal of applied psychology, 88(5). 879-903. DOI: $10.1037 / 0021-9010.88 .5 .879$

VAN GELDER, M. , BRETVELD, R. W., ROELEVELD, N. 2010. Web-based questionnaires: The future in epidemiology? Internet versus paper-and-pencil survey methods in psychological experiments: Equivalence testing of participant responses to health-related messages. In: American Journal of Epidemiology, 172, 1292-1298.

RAMMSTEDT, B., JOHN, O. P. 2007. Measuring personality in one minute or less: A 10-item short version of the Big Five Inventory in English and German. In: Journal of Research in Personality. 41 , 203-212. ISSN: 0092-6566. http://www.sciencedirect.com/science/article/pii/S0092656606000195

RICE, L., \& MARKEY, P. M. 2009. The role of extraversion and neuroticism in influencing anxiety following computer-mediated interactions. In: Personality and Individual Differences, 46 (1), 35-39. http://dx.doi.org/10.1016/j.paid.2008. 08.022

RYAN, T., XENOS, S. 2011. 'Who uses Facebook? An investigation into the relationship between the Big Five, shyness, narcissism, loneliness, and Facebook usage', In: Computers in Human Behavior, 27 (5), 1658-1664.

SAINI, V. K., BANIYA, G. CH., VERMA, K. K., SONI, A., KESHAWANI, S. 2016. A study on relationship of internet addictive behavior with personality traits among medical students. In: Journal of Mental Health and Human Behaviour, 21(2), 108-111.

SIOMOS, K. E., DAFOULI, E. D., BRAIMIOTIS, D. A., MOUZAS, O. D., \& ANGELOPOULOS, N. V. 2008. Internet addiction among Greek adolescent students. In: CyberPsychology \& Behavior, 11 (6), 653-657.

SLOVAK REPUBLIC. 2017. Law no. 369/1990, § 22 "The Law about General Settlement" http://www.zakonypreludi.sk/zz/1990-369

STEPANIKOVA, I., Nie, N. H., \& He, X. 2010. Time on the Internet at home, loneliness, and life satisfaction: Evidence from panel time-diary data. Computers in Human Behavior, 26(3), 329. 338.

TAKESHI, S. 2006. Internet Addiction among Students: Prelevance and psychological problems in $\begin{array}{lllll}\text { Japan. } & \text { In } & J M A J & 49 & \text { (7-8). }\end{array}$ http://www.med.or.jp/english/pdf/2006_07\%2B/279_283.pdf

VRABEC, N. 2009. On-line generácia: informácie, komunikácia a digitálna participácia mládeže v informačnej spoločnosti: výskumná správa. Bratislava: MŠ SR a IUVENTA. 59 s. http://www.iuventa.sk/files/documents/7_vyskummladeze/spravy/davm027/on_line_genera cia_publikacia.pdf

WEST, R. 2013. Models of addiction. In EMCDDA Insights [online]. No. 14, 161p. ISSN 2314-9264. http://www.emcdda.europa.eu/ publications/insights/models-addiction

UYENCO, B., KINGDON, A. 2010. Young Adults Revealed: The lives and motivations of 21st century youth, advertising.microsoft.com/ wwdocs/.../Young-Adults-Revealed.pdf,

YOUNG, K. S. 1996. Internet addiction: The emergence of a new clinical disorder. In: Cyber Psychology $\begin{array}{llll}\text { and } \quad \text { Behavior. } & \text { 237-244. ISSN } & \text { 1094-9313. }\end{array}$ http://www.chabad4israel.org/tznius4israel/newdisorder.pdf

YOUNG, K. 1998. Internet addiction: The emergence of a new clinical disorder. In: CyberPsychology and Behavior, 1, 237-244.

YOUNG, K., ROGERS, R. C. 1998. The Relationship between depression and Internet Addiction. In: CyberPsychology \& Behavior, 1(1): 25-28. https://doi.org/10.1089/cpb.1998. 1.25

YANG, S., \& TUNG, C. 2007. Comparison of Internet addicts and non-addicts in Taiwanese high school. In: Computers in Human Behavior, 23, 79-96. 
TOSUN, N. - BARIS, M. F. 2011. The Place and Importance of Computer and Internet's In Secondary School Students' Life. In: Procedia Social and Behavioral Sciences 28, 530 - 535.

TSAI, C. C., \& LIN, C.C. 2004. Taiwanese adolescents' perceptions and attitudes regarding the Internet: Exploring gender differences. In: Adolescence, 39, 725-734.

TSAI, H. F., CHENG, S. H., YEH, T. L., SHIH, C. C., CHEN, K. C., YANG, Y. C., YANG, Y. K. 2009. The risk factors of internet addiction-A survey of university freshmen. In: Psychiatry Research, 167, 294-299.

ZAMANI, B. E., ABEDINI, Y., KHERADMAND, A. 2011. Internet Addiction Based on Personality Characteristics of High School Students in Kerman, Iran. In: Addict Health. Summer-Autumn; 3(3-4), 85-91.

\section{Marián Host'ovecký,}

Department of Applied Informatics and Mathematics,

University of Ss. Cyril and Methodius, Slovakia, 91701

Email: marian.hostovecky@ucm.sk

\section{Pavol Prokop,}

Department of Biology, Faculty of Education,

Trnava University in Trnava, Slovakia, 91701

Email: pavol.prokop@truni.sk

Received April 2018 